\title{
Article \\ Sublethal Effects of Chlorantraniliprole on Spodoptera litura (Lepidoptera: Noctuidae) Moth: Implication for Attract-and-Kill Strategy
}

\author{
Fanfang Kong ${ }^{1,+}$, Yaqin Song ${ }^{2,+}$, Qian Zhang ${ }^{1}$, Zhongyue Wang ${ }^{1}$ and Yongqiang Liu ${ }^{1, *}$ \\ 1 State Key Laboratory for Biology of Plant Diseases and Insect Pests, Institute of Plant Protection, \\ Chinese Academy of Agricultural Sciences, Beijing 100193, China; fanfang103@126.com (F.K.); \\ zhangqian9405@163.com (Q.Z.); wangzhy0301@sina.com (Z.W.) \\ 2 Guangxi Academy of Specialty Crops, Guilin 541004, China; wrongpiano@163.com \\ * Correspondence: liuyongqiang@caas.cn \\ + These authors contributed equally to this work.
}

Citation: Kong, F.; Song, Y.; Zhang, Q.; Wang, Z.; Liu, Y. Sublethal Effects of Chlorantraniliprole on Spodoptera litura (Lepidoptera: Noctuidae) Moth: Implication for Attract-and-Kill Strategy. Toxics 2021, 9, 20. https:// doi.org/10.3390/toxics 9020020

Received: 2 December 2020 Accepted: 12 January 2021 Published: 22 January 2021

Publisher's Note: MDPI stays neutral with regard to jurisdictional clai$\mathrm{ms}$ in published maps and institutional affiliations.

Copyright: (C) 2021 by the authors. Licensee MDPI, Basel, Switzerland. This article is an open access article distributed under the terms and conditions of the Creative Commons Attribution (CC BY) license (https:// creativecommons.org/licenses/by/ $4.0 /)$.

\begin{abstract}
The integrated use of plant-derived volatile attractants and synthetic insecticides in attractand-kill programs is a useful tool for integrated pest management programs reducing pesticide input. Efficient alternative insecticides are critically needed to replace methomyl, which has been banned on cruciferous vegetables in China because it is also highly toxic to nontarget organisms. In the present study, among 15 commonly used insecticides were screened for toxicity against S. litura moths, where chlorantraniliprole, flubendiamide, and emamectin benzoate was found to have the highest levels of toxicity ( $\mathrm{LC}_{50}$ of $0.56,3.85$, and $6.03 \mathrm{mg}$ a.i. $\mathrm{L}^{-1}$ respectively). After exposure to the low lethal concentration $\mathrm{LC}_{50}$ of chlorantraniliprole, fecundity of the moths was substantially reduced. Egg-hatching was lower for $\mathrm{LC}_{20^{-}}$and $\mathrm{LC}_{50}$-treated moth pairs than for untreated control pairs. Net reproductive rate $\left(R_{0}\right)$, intrinsic rate of increase $(r)$, and finite rate of increase $(\lambda)$ were significantly reduced in $\mathrm{LC}_{50} 9 \times \mathrm{LC}_{50} 0^{7}$ cohorts. Larval mortality was significantly higher in subsequent generations in pairs of $\mathrm{LC}_{50}$-treated moths. Chlorantraniliprole, which was most toxic and had significant sublethal effects on moths, can be used as an alternative insecticide to methomyl in the attracticide for controlling $S$. litura moths, and the $\mathrm{LC}_{50}$ indicated a high potential for efficacy in the control S. litura through attract-and-kill schemes.
\end{abstract}

Keywords: Spodoptera litura; moth; chlorantraniliprole; sublethal effects; reproduction

\section{Introduction}

The tobacco caterpillar, Spodoptera litura Fab. (Lepidoptera, Noctuidae), is a serious pest of many agricultural crops, such as soybean (Glycine max L.), maize (Zea mays L.), and vegetables and fruit trees in the southern and eastern regions of Asia [1-3]. Losses from their feeding can range from 26 to $100 \%$ in the field [3]. At present, chemical insecticides are still the main method to control S. litura, and they usually target the larvae [4].

In China, the range of $S$. litura in China can be divided into three zones: the year-round breeding region, the overwintering region, and the summer breeding region [5-7]. Due to the high reproductive capacity of the adults and their ability to migrate long distances, populations of the pest can expand rapidly in the summer breeding region [8,9]. Therefore, the adult stage is also the key target for managing pest populations.

The attract-and-kill strategy is a potential tactic in the management of agricultural pests that presupposes the intelligent combination of an attracting agent (e.g., host kairomone) and a killing agent (e.g., insecticide) [10]. Such an approach can significantly decrease egg production and subsequent larval populations [11]. Recently, attractants consisting of synthetic plant volatiles (aromatic information compounds) and toxicants have been developed for trapping both sexes of noctuidae adults including S. litura [12]. In China, 
researchers have developed an attracticide for lepidopteran pests of cotton (Gossypium spp.), maize (Zea mays L.), and peanut (Arachis hypogaea L.) [13-15]. Methomyl is presently the major pesticide used for this purpose [16]; however, its use on cruciferous vegetables has been banned in China because it is highly toxic to nontarget organisms [17]. Therefore, an alternative to methomyl is needed to use in attracticides.

The extensive literature on the toxicity and effectiveness of various insecticides against S. litura, is almost entirely concentrated on the larvae [18-20] because the larvae harms plants directly and are the usual targets of insecticides. Less information is available on the oral toxicity of insecticides against adults of $S$. litura. An attracticide must rapidly incapacitate and kill moths to prevent them from laying eggs before they die; thus, the concentration of an insecticide in the attracticide is important. Because all pesticides can elicit sublethal effects on pests [21,22], we need to investigate the sublethal effects of insecticides that are highly toxic to $S$. litura moths so that the dosage can be reduced in attractants.

Against this background, here we evaluated the susceptibility of S. litura moths to 15 common insecticides. Further, we investigated the sublethal effects of the most effective insecticide, chlorantraniliprole, on adults of S. litura and highlight that chlorantraniliprole at low doses would be effective in the attract-and kill against $S$. litura.

\section{Materials and Methods}

\subsection{Insect and Insecticide}

S. litura moths were captured by a searchlight trap at the Langfang Experimental Station $\left(39.53^{\circ} \mathrm{N}, 116.70^{\circ} \mathrm{E}\right)$, Chinese Academy of Agricultural Sciences (CAAS), in Hebei Province, China. Then, they were stored in cages with mesh sides for egg collection. The larvae of $S$. litura were reared on an artificial diet $[23,24]$ under conditions of $25 \pm 1{ }^{\circ} \mathrm{C}$ and $60 \pm 5 \%$ relative humidity with a 14:10 light:dark photoperiod. All moths were provided with a solution of $10 \% v / v$ sugar and $2 \% v / v$ vitamin complex for nutrition supplement. Adults of the third and fourth generations were used for bioassays. For experiments on sublethal effects of chlorantraniliprole on $S$. litura moths, the insects were sexed after pupation and placed separately in ventilated plastic cages for emergence. Moths were used within $24 \mathrm{~h}$ of emergence.

Insecticides were technical grade formulations ( $\% w / v$, as indicated) of 15 insecticides were tested as follows: chlorantraniliprole (95.3\%), cyhalothrin (95\%), thiodicarb (95\%), flubendiamide (98\%), abamectin (97\%), spinosad $(90 \%)$, indoxacarb $(94 \%)$, emamectin benzoate (92\%), chlorfenapyr (94.5\%), beta-cypermethrin $(96.5 \%)$, fenpropathrin (92\%), fenvalerate (96\%), chlorpyrifos (98\%), carbosulfan (90\%). All insecticides were provided by the Institute for the Control of Agrochemicals (ICA), the Ministry of Agriculture (MOA), China. A spinetoram suspension concentrate (SC) $\left(50,000 \mathrm{mg}\right.$ a.i. $\left.\mathrm{L}^{-1}\right)$ was obtained from Langfang, China (Produced by Dow AgroSciences, UK).

\subsection{Bioassay of S. litura Moths in the Laboratory}

A $100 \mathrm{~mL}$ stock solution $\left(10,000 \mathrm{mg}\right.$ a.i. $\left.\mathrm{L}^{-1}\right)$ of spinetoram was prepared in distilled water, while all other stock solutions $\left(50,000 \mathrm{mg}\right.$ a.i. $\left.\mathrm{L}^{-1}\right)$ of insecticides were diluted using dimethyl sulfoxide (DMSO). Each stock solution was diluted using a $10 \% v / v$ honey solution containing $0.1 \% v / v$ Tween-80 to the desired experimental concentrations (Beijing Chemical Reagent Co. Ltd., Beijing, China). The $10 \%$ honey solution containing $1 \%$ DMSO and $0.1 \%$ Tween- 80 was used as a blank control. To prevent insect contact with the insecticide solution, the cotton ball with insecticide or honey solution was placed on the bottom of a plastic cup $(7.4 \mathrm{~cm}$, top diameter; $9.7 \mathrm{~cm}$, height). Next, a bottomless plastic cylinder that was $9.5 \mathrm{~cm}$ high $(7.4 \mathrm{~cm}$, top diameter) was wrapped with two layers of cotton gauze and placed inside this cup, maintaining $\sim 0.8 \mathrm{~mm}$ between the gauze and soaked cotton ball. Five $S$. litura moths ( 3 days old) were randomly chosen and placed in each cylinder as one replicate; all bioassay treatments had five replications. All cylinders were maintained at $25 \pm 1{ }^{\circ} \mathrm{C}, 60 \pm 5 \% \mathrm{RH}$, and had a photoperiod of $14: 10 \mathrm{~h}(\mathrm{~L}$ : D). The 
mortality rate of moths in the cylinder was observed after $24 \mathrm{~h}$. For sublethal effects of chlorantraniliprole to $S$. litura moths, $\mathrm{LC}_{20}, \mathrm{LC}_{50}$, and $\mathrm{LC}_{90}$ values were calculated.

\subsection{Sublethal Effects on Reproduction}

Five S. litura moths of the same sex were placed into a plastic cup, as described in Section 2.2. The cotton ball with chlorantraniliprole at sublethal doses $\left(\mathrm{LC}_{20}\right.$ and $\left.\mathrm{LC}_{50}\right)$ and $10 \%$ honey solution was placed on the bottom of the plastic cup. To obtain enough live moths treated with different doses of chlorantraniliprole, 80 replicates (400 females and 400 males) were subjected to the $\mathrm{LC}_{50}$ treatment, 60 replicates (300 females and 300 males) to the $\mathrm{LC}_{20}$ treatment, and 60 replicates ( 300 females and 300 males) to the control treatment.

After $24 \mathrm{~h}$, the female and male moths from the different treatments were paired. The mating patterns were as follows: $\mathrm{LC}_{50} \uparrow \times \mathrm{LC}_{50} 0^{7}, \mathrm{LC}_{50}$ \% $\times \mathrm{CK}^{7}, \mathrm{CK} \uparrow \times \mathrm{LC}_{500^{7}}, \mathrm{LC}_{20}$ \% $\times \mathrm{LC}_{20} 0^{7}$, $\mathrm{LC}_{20}+\times \mathrm{CKo}^{7}, \mathrm{CK}+\times \mathrm{LC}_{20} 0^{7}$, and $\mathrm{CK}+\times \mathrm{CK}^{\circ}$. Each pair was placed in a plastic cup $(7.4 \mathrm{~cm}$, top diameter; $9.7 \mathrm{~cm}$, height), and $10 \%$ honey solution was provided as food for moths. The top of the plastic cup was covered with gauze for oviposition. Eggs on the gauze were counted, and new gauze was placed on the plastic daily. Egg-hatching was recorded for a random subset of approximately 150-200 eggs. For this purpose, sections of cotton gauze with S. litura eggs were placed in Petri dishes ( $3.5 \mathrm{~cm}$, diameter; $1 \mathrm{~cm}$, height) and examined for seven consecutive days. Adult longevity was also recorded. One hundred replicates were used for each treatment.

\subsection{Sublethal Effects on Traits of Offspring}

The $\mathrm{LC}_{20}$ and $\mathrm{LC}_{50}$ concentrations were used to assess the sublethal effects of chlorantraniliprole on S. litura. To determine the $\mathrm{LC}_{20}$ and $\mathrm{LC}_{50}$ concentrations, we first generated a concentration-mortality regression line, then calculated the respective concentrations from the regression lines (see Section 3). Newly hatched S. litura larvae were randomly sampled from each treatment (see Section 2.3) and placed into a 24-well plate (one larvae per well) with an artificial diet. Three replicates (20 larvae per replicate) were used for each treatment. All plates were maintained in controlled incubators $\left(27 \pm 1{ }^{\circ} \mathrm{C}\right.$, $50 \pm 10 \%$ RH, 14L: 10D). All insects were examined daily, and the developmental period, pupa mass, adult emergence (number of pupae that eclosed to adults divided by number of pupae, multiplied by 100), and larvae mortality (number of larvae that not pupated divided by number of larvae examined, multiplied by 100) were recorded.

\subsection{Data Analysis}

The median lethal concentrations, $95 \%$ confidence limits (CLs), and slope \pm SE were calculated using probit analysis. One-way analysis of variance (ANOVA) was used to analyze the effects of lethal concentrations of chlorantraniliprole on female longevity, male longevity, fecundity, egg-hatching rate, developmental period, pupa weight, adult emergence, and larvae mortality, followed by Tukey's honestly significant difference (HSD) test $(p<0.05)$ using SPSS 13.0 software (SPSS Inc., Chicago, IL, USA) [25]. The selected S. litura population parameters, including the net reproductive rate $\left(R_{0}\right)$, intrinsic rate of increase $(r)$, finite rate of increase $(\lambda)$, and mean generation time $(\mathrm{T})$ were analyzed according to the age-stage, two-sex life table theory, using the program TWOSEX-MSChart [26]. Means, standard errors, and significant differences were calculated using a bootstrap procedure in TWOSEX-MSChart, with 100,000 replications [27]. Before analysis, all data were tested for normality and homogeneity of variances. Statistical analysis was performed using GraphPad Prism software [28].

\section{Results}

\subsection{Insecticide Toxicity to S. litura Moths}

Toxicities of insecticides to the $S$. litura moths varied considerably, but mortality was consistently $<5 \%$ in the control groups (Table 1). The order of toxicity (from high to low) for the 15 insecticides was chlorantraniliprole $>$ flubendiamide $>$ emamectin benzoate, 
fenpropathrin > chlorpyrifos, fenvalerate, indoxacarb > lambda-cyhalothrin, beta cypermethrin, thiodicarb > avermectin, spinetoram, spinosad, carbosulfan, and chlorfenapyr ( $\mathrm{LC}_{50}$ values with overlapping $95 \%$ confidence intervals were classified as having the same level of toxicity). The toxicity of chlorantraniliprole was the highest among the tested insecticides, with an $\mathrm{LC}_{50}$ value of $0.56 \mathrm{mg}$ a.i. liter ${ }^{-1}$, while avermectin, spinetoram, spinosad, carbosulfan, and chlorfenapyr had the lowest toxicity, with $\mathrm{LC}_{50}$ values $>100 \mathrm{mg}$ a.i. liter $^{-1}$ (Table 1).

Table 1. Toxicity of 15 insecticides to S. litura moths ( $24 \mathrm{~h})$.

\begin{tabular}{|c|c|c|c|c|c|}
\hline Insecticide & Slope \pm SE & $\mathrm{LC}_{50}\left(\mathrm{mg}\right.$ a.i. Liter $\left.{ }^{-1}\right)$ & 95\% Fiducial Limits & $R^{2}(\mathrm{df})$ & $p$ \\
\hline Chlorantraniliprole & $2.126 \pm 0.170$ & 0.56 & $0.48 \sim 0.67$ & $20.506(16)$ & 0.1983 \\
\hline Flubendiamide & $2.392 \pm 0.237$ & 3.85 & $3.25 \sim 4.53$ & $6.314(13)$ & 0.934 \\
\hline Emamectin benzoate & $1.962 \pm 0.179$ & 6.03 & $5.01 \sim 7.23$ & $7.535(16)$ & 0.9615 \\
\hline Fenpropathrin & $2.153 \pm 0.226$ & 7.31 & $6.12 \sim 8.88$ & $4.187(13)$ & 0.989 \\
\hline Chlorpyrifos & $1.814 \pm 0.170$ & 13.29 & $10.88 \sim 16.09$ & $4.106(16)$ & 0.9987 \\
\hline Fenvalerate & $1.714 \pm 0.206$ & 16.57 & $13.02 \sim 20.47$ & $5.275(13)$ & 0.9686 \\
\hline Indoxacarb & $2.224 \pm 0.231$ & 17.36 & $14.42 \sim 20.63$ & $8.300(13)$ & 0.8234 \\
\hline Lambda-cyhalothrin & $1.691 \pm 0.163$ & 28.12 & $22.94 \sim 34.48$ & $7.432(16)$ & 0.964 \\
\hline Beta cypermethrin & $1.681 \pm 0.162$ & 33.83 & $23.34 \sim 51.08$ & $44.476(16)$ & 0.0002 \\
\hline Thiodicarb & $2.362 \pm 0.235$ & 41.16 & $34.72 \sim 48.54$ & $5.284(13)$ & 0.9684 \\
\hline Avermectin & & $>100$ & & & \\
\hline Spinetoram & & $>100$ & & & \\
\hline Spinosad & & $>100$ & & & \\
\hline Carbosulfan & & $>100$ & & & \\
\hline Chlorfenapyr & & $>100$ & & & \\
\hline
\end{tabular}

\subsection{Lethal Effects of Chlorantraniliprole on S. litura Moths}

Based on the mortality records for the six experimental treatments, the $\mathrm{LC}_{20}$ and $\mathrm{LC}_{50}$ value was 0.245 and $0.561 \mathrm{mg} \cdot \mathrm{L}^{-1}$, respectively (Figure 1 ). The $\mathrm{LC}_{50}$ and $\mathrm{LC}_{20}$ value was used as the lethal and low-lethal concentrations, respectively, in subsequent experiments.

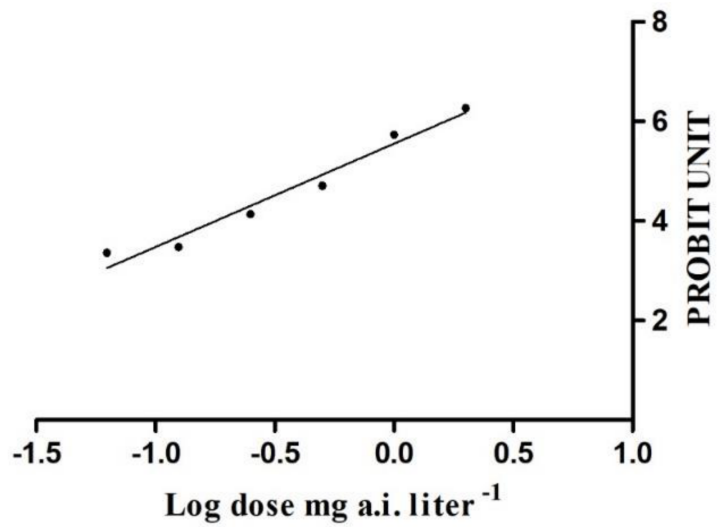

Figure 1. Linear regression of morality (probit unit) of Spodoptera litura and chlorantraniliprole concentration (logtransformed).

\subsection{Adult Reproduction}

The longevity of female adults was significantly reduced by $\mathrm{LC}_{50}$ and $\mathrm{LC}_{20}$ compared with the control $(\mathrm{F}=12.46, \mathrm{df}=2,18, p<0.001)$. The longevity of male adults was reduced by the $\mathrm{LC}_{50}$ treatment, but not significantly compared with the control $(\mathrm{F}=4.34, \mathrm{df}=2,18$, $p=0.029$ ). Fecundity of female adults significantly decreased in the $\mathrm{LC}_{50}$ $9 \times \mathrm{LC}_{50} \mathrm{c}^{7}$ cohorts compared with the control $(\mathrm{F}=6.40, \mathrm{df}=6,14, p=0.002)$. Furthermore, the egg-hatching rate in the $\mathrm{LC}_{50} 9 \times \mathrm{LC}_{50} 0^{7}, \mathrm{LC}_{50} 9 \times \mathrm{CK}^{\circ}, \mathrm{CK}+\times \mathrm{LC}_{500^{7}}$, and $\mathrm{LC}_{20} \% \times \mathrm{LC}_{20} 0^{7}$ cohorts was significantly lower than in the control treatments $(\mathrm{F}=13.42, \mathrm{df}=6,14, p<0.001)$ (Figure 2). 

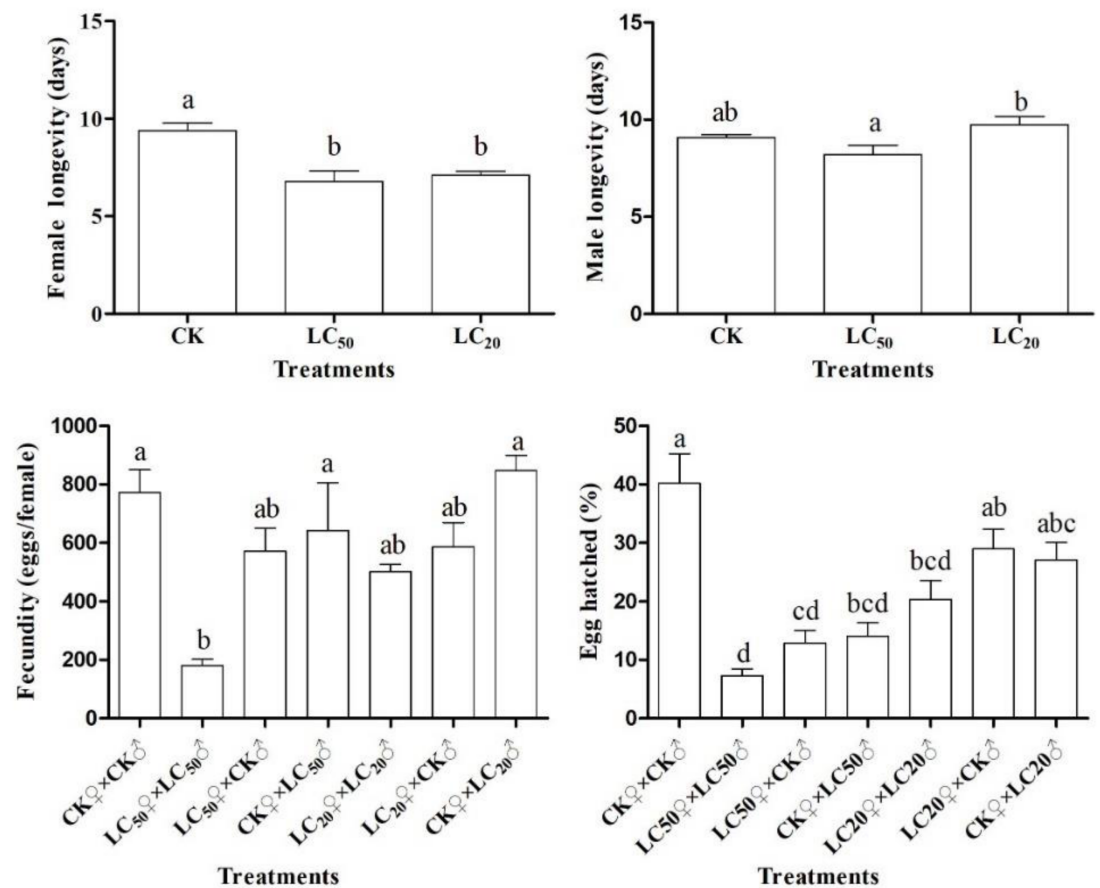

Figure 2. Effects of chlorantraniliprole at sublethal doses on the longevity and fecundity of Spodoptera litura after treatment in the adults. $\mathrm{CK}_{9}, \mathrm{LC}_{20}$ ㅇ, and $\mathrm{LC}_{50}$ क mean the surviving females from control, and $\mathrm{LC}_{20}$ and $\mathrm{LC}_{50}$ are the treated cohorts that were used to pair with males, respectively; $\mathrm{CKo}^{7}$, $\mathrm{LC}_{20} 0^{7}$, and $\mathrm{LC}_{50} 0^{7}$ mean the surviving males from control, and $\mathrm{LC}_{20}$ and $\mathrm{LC}_{50}$ are the treated cohorts that were used to pair with females, respectively. "Fecundity" is the number of eggs laid per female. Different letters above bars indicate a significant intermonth difference at the 5\% level in Tukey's HSD tests.

\section{4. $F_{1}$ Generation Developmental Duration}

For S. litura offspring, adult emergence for the $\mathrm{LC}_{50}+\times \mathrm{LC}_{50} 0^{7}$ cohorts $(65.50 \pm 1.17 \%)$ was significantly lower than control treatments $(85.09 \pm 0.78 \%)(\mathrm{F}=4.922, \mathrm{df}=6,14$,

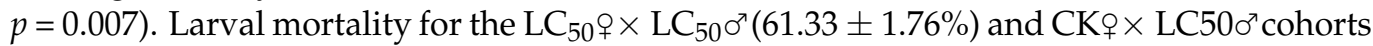
$(44.67 \pm 4.06 \%)$ was significantly higher than for the control treatment $(24.00 \pm 2.00 \%)$ $(\mathrm{F}=16.237, \mathrm{df}=6,14, p<0.001)$ (Table 2).

Table 2. Effects of chlorantraniliprole at sublethal doses on the life history traits of the offspring of Spodoptera litura after treatment in the adults.

\begin{tabular}{|c|c|c|c|c|c|c|c|c|c|}
\hline \multirow[b]{2}{*}{ Treatment } & \multicolumn{9}{|c|}{ Development } \\
\hline & 1st Instar (Days) & 2nd Instar (Days) & 3rd Instar (Days) & 4th Instar (Days) & 5th Instar (Days) & 6th Instar (Days) & $\begin{array}{l}\text { Pupa Weight } \\
\text { (mg) }\end{array}$ & $\begin{array}{c}\text { Adult Emergence } \\
(\%)\end{array}$ & $\begin{array}{c}\text { Larval Mortality } \\
(\%)\end{array}$ \\
\hline $\mathrm{CK}+\times \mathrm{CKO}^{\circ}$ & $3.36 \pm 0.07 \mathrm{~d}$ & $2.69 \pm 0.08 \mathrm{~d}$ & $2.95 \pm 0.10 \mathrm{~b}$ & $3.00 \pm 0.11 \mathrm{bc}$ & $3.12 \pm 0.12 \mathrm{~cd}$ & $3.86 \pm 0.15 \mathrm{a}$ & $452.86 \pm 10.58 \mathrm{ab}$ & $85.09 \pm 0.78 \mathrm{a}$ & $24.00 \pm 2.00 \mathrm{~cd}$ \\
\hline $\mathrm{LC}_{50} \% \times \mathrm{LC}_{50}$ o $^{x}$ & $3.46 \pm 0.14 \mathrm{~cd}$ & $2.99 \pm 0.09 \mathrm{~cd}$ & $3.00 \pm 0.16 \mathrm{~b}$ & $3.37 \pm 0.07 \mathrm{ab}$ & $3.14 \pm 0.18 \mathrm{c}$ & $4.07 \pm 0.18 \mathrm{a}$ & $411.90 \pm 16.41 \mathrm{~b}$ & $65.50 \pm 1.17 \mathrm{~b}$ & $61.33 \pm 1.76 \mathrm{a}$ \\
\hline $\mathrm{LC}_{50} q \times \mathrm{CK}^{\circ}$ & $5.14 \pm 0.16 \mathrm{a}$ & $3.14 \pm 0.01 \mathrm{bc}$ & $3.04 \pm 0.06 \mathrm{~b}$ & $2.49 \pm 0.05 \mathrm{c}$ & $2.18 \pm 0.02 \mathrm{~d}$ & $1.91 \pm 0.10 \mathrm{c}$ & $503.88 \pm 14.90 \mathrm{a}$ & $88.14 \pm 3.77 \mathrm{a}$ & $38.67 \pm 4.06 \mathrm{bc}$ \\
\hline $\mathrm{CK}+\times \mathrm{LC}_{50} \sigma^{77}$ & $3.52 \pm 0.15 \mathrm{bcd}$ & $3.39 \pm 0.11 \mathrm{ab}$ & $4.72 \pm 0.44 \mathrm{a}$ & $3.67 \pm 0.27 \mathrm{a}$ & $3.14 \pm 0.16 \mathrm{c}$ & $2.76 \pm 0.18 \mathrm{~b}$ & $418.02 \pm 12.37 \mathrm{~b}$ & $77.51 \pm 2.92 \mathrm{ab}$ & $44.67 \pm 4.06 \mathrm{ab}$ \\
\hline $\mathrm{LC}_{20^{\circ}} \times \mathrm{LC}_{20} 0^{\pi}$ & $4.09 \pm 0.13 \mathrm{~b}$ & $3.42 \pm 0.08 \mathrm{ab}$ & $2.40 \pm 0.06 \mathrm{~b}$ & $3.23 \pm 0.07 \mathrm{ab}$ & $4.84 \pm 0.22 \mathrm{~b}$ & $2.15 \pm 0.01 \mathrm{c}$ & $413.47 \pm 18.77 \mathrm{~b}$ & $73.11 \pm 8.63 \mathrm{ab}$ & $15.33 \pm 8.35 \mathrm{~d}$ \\
\hline $\mathrm{LC}_{20} \uparrow \times \mathrm{CK}^{\circ}$ & $3.84 \pm 0.06 \mathrm{bcd}$ & $3.48 \pm 0.03 \mathrm{ab}$ & $2.28 \pm 0.02 \mathrm{~b}$ & $3.22 \pm 0.01 \mathrm{ab}$ & $5.27 \pm 0.22 b$ & $1.99 \pm 0.01 \mathrm{c}$ & $397.45 \pm 4.47 \mathrm{~b}$ & $82.56 \pm 1.17 \mathrm{ab}$ & $23.33 \pm 2.40 \mathrm{~cd}$ \\
\hline $\mathrm{CK}+\times \mathrm{LC}_{20} \sigma^{7}$ & $3.99 \pm 0.20 \mathrm{bc}$ & $3.57 \pm 0.10 \mathrm{a}$ & $2.53 \pm 0.06 \mathrm{~b}$ & $3.40 \pm 0.09 \mathrm{ab}$ & $6.49 \pm 0.28 \mathrm{a}$ & $1.98 \pm 0.05 \mathrm{c}$ & $421.74 \pm 5.48 \mathrm{~b}$ & $88.79 \pm 1.91 \mathrm{a}$ & $16.00 \pm 3.06 \mathrm{~d}$ \\
\hline
\end{tabular}

The abbreviations $\mathrm{CK}_{9}, \mathrm{LC}_{20} 9$, and $\mathrm{LC}_{50}$ indicate, respectively, the surviving females from the control and $\mathrm{LC}_{20}-$ and $\mathrm{LC}_{50}$-treated cohorts that were paired with males; $\mathrm{CKO}^{7}, \mathrm{LC}_{20} 0^{7}$, and $\mathrm{LC}_{50} 0^{7}$ indicate, respectively, the surviving males from the control and $\mathrm{LC}_{20}$ and $\mathrm{LC}_{50}$-treated cohorts that were paired with females. Different letters within a column indicate a significant intermonth difference at the $5 \%$ level in Tukey's HSD tests.

\subsection{Life History Parameters}

Net reproductive rate $\left(R_{0}\right)$ was significantly reduced for $\mathrm{LC}_{50}$ 으 $\mathrm{LC}_{50} \mathrm{\sigma}^{7}(2.44 \pm 0.58)$ and $\mathrm{LC}_{50}$ $\times \mathrm{CKo}^{7}(47.99 \pm 17.23)$ cohorts compared to the control (137.43 \pm 22.43$)$. The intrinsic rate of increase $(r)$ was the lowest for $\mathrm{LC}_{50}+\times \mathrm{LC}_{50} 0^{7}$ cohorts $(0.03 \pm 0.01)$, followed by the $\mathrm{LC}_{50}+\times \mathrm{CKo}^{7}(0.14 \pm 0.02), \mathrm{CK}_{+} \times \mathrm{LC}_{50} 0^{7}(0.14 \pm 0.01), \mathrm{LC}_{20}$ $+\times \mathrm{LC}_{20} 0^{7}(0.15 \pm 0.01)$, and $\mathrm{CK} q \times \mathrm{LC}_{20} 0^{7}$ cohorts $(0.15 \pm 0.01)$, which were all significantly lower than that of the 
control $(0.18 \pm 0.01)$. The finite rate of increase $(\lambda)$ was the lowest for $\mathrm{LC}_{50}$ \% $\times \mathrm{LC}_{50} 0^{7}$ cohorts $(1.03 \pm 0.01)$, followed by $\mathrm{LC}_{50}$ 우 $\times \mathrm{CK}^{7}(1.15 \pm 0.02), \mathrm{CK}+\times \mathrm{LC}_{50} \mathrm{\sigma}^{7}(1.15 \pm 0.01), \mathrm{LC}_{20}$ 우 $\times \mathrm{LC}_{20} \mathrm{\sigma}^{7}$ $(1.16 \pm 0.01)$, and $\mathrm{CK}+\times \mathrm{LC}_{20} 0^{7}$ cohorts $(1.16 \pm 0.01)$, which were all significantly lower than that of the control $(1.20 \pm 0.01)$ (Table 3$)$.

Table 3. Effects of chlorantraniliprole at sublethal doses on the life-table parameters of Spodoptera litura after treatment in the adults.

\begin{tabular}{|c|c|c|c|c|}
\hline Treatments & $\begin{array}{c}\text { Net Reproductive } \\
\text { Rate }\left(\boldsymbol{R}_{0}\right)\end{array}$ & $\begin{array}{c}\text { Intrinsic Rate of } \\
\text { Increase }(r)\end{array}$ & $\begin{array}{l}\text { Finite Rate of Increase } \\
(\lambda)\end{array}$ & $\begin{array}{c}\text { Mean Generation } \\
\text { Time }(T)\end{array}$ \\
\hline CKo $\times \mathrm{CK}^{\mathrm{T}}$ & $137.43 \pm 22.43 a$ & $0.18 \pm 0.01 \mathrm{a}$ & $1.20 \pm 0.01 \mathrm{a}$ & $27.35 \pm 0.54 \mathrm{~d}$ \\
\hline $\mathrm{LC}_{50} \mathrm{q} \times \mathrm{LC}_{50} \sigma^{7}$ & $2.44 \pm 0.58 c$ & $0.03 \pm 0.01 \mathrm{c}$ & $1.03 \pm 0.01 \mathrm{c}$ & $28.72 \pm 0.47 \mathrm{~cd}$ \\
\hline $\mathrm{LC}_{50}+\times \mathrm{CK}^{\top}$ & $47.99 \pm 17.23 \mathrm{~b}$ & $0.14 \pm 0.02 \mathrm{~b}$ & $1.15 \pm 0.02 \mathrm{~b}$ & $27.99 \pm 0.54 \mathrm{~d}$ \\
\hline $\mathrm{CK}_{+} \times \mathrm{LC}_{50} \sigma^{7}$ & $88.68 \pm 29.43 \mathrm{ab}$ & $0.14 \pm 0.01 \mathrm{~b}$ & $1.15 \pm 0.01 \mathrm{~b}$ & $31.39 \pm 0.99 \mathrm{ab}$ \\
\hline $\mathrm{LC}_{20} \rho \times \mathrm{LC}_{20} \sigma^{x}$ & $110.58 \pm 31.51 \mathrm{ab}$ & $0.15 \pm 0.01 \mathrm{~b}$ & $1.16 \pm 0.01 \mathrm{~b}$ & $31.02 \pm 0.58 \mathrm{ab}$ \\
\hline 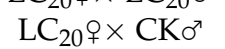 & $123.39 \pm 28.81 \mathrm{a}$ & $0.16 \pm 0.01 \mathrm{ab}$ & $1.17 \pm 0.01 \mathrm{ab}$ & $30.02 \pm 0.50 \mathrm{bc}$ \\
\hline $\mathrm{CK}_{+} \times \mathrm{LC}_{20} \sigma^{\top}$ & $140.63 \pm 29.46 a$ & $0.15 \pm 0.01 \mathrm{~b}$ & $1.16 \pm 0.01 \mathrm{~b}$ & $32.47 \pm 0.57 \mathrm{a}$ \\
\hline
\end{tabular}

$\mathrm{CK}$, $\mathrm{LC}_{20}$ \%, and $\mathrm{LC}_{50}$ omean the surviving females from control, and $\mathrm{LC}_{20}$ and $\mathrm{LC}_{50}$ are the treated cohorts used to pair with males, respectively; $\mathrm{CK}^{7}, \mathrm{LC}_{20} \mathrm{\sigma}^{7}$, and $\mathrm{LC}_{50} \mathrm{\sigma}^{7}$ mean the surviving males from control, and $\mathrm{LC}_{20}$ and $\mathrm{LC}_{50}$ are the treated cohorts used to pair with females, respectively. Values that are followed by a different letter(s) within a column differed significantly at $p<0.05$ using the bootstrap procedure in the TWOSEXMS Chart, with 100,000 replications, for $R_{0}, r, \lambda$, and $T$ ).

\section{Discussion}

An attracticide, a combination of synthetic plant volatiles and an insecticide, is used to trap and control lepidopteran moths $[17,29,30]$. However, research has focused on the toxicity and sublethal effects of insecticides on lepidopteran larvae [18,21,31-34]. There are many kinds of insecticides to be selected for larval control in most cases, and the sublethal doses of insecticides on larvae could adversely affect the developmental and reproductive traits, and lead to a population decrease [21,32-34]. Little work has yet explored the toxicity and sublethal effects of insecticides on S. litura moths. In this study of the toxicity of 15 insecticides commonly used against $S$. litura moths, chlorantraniliprole had highest toxicity against $S$. litura moths. Therefore, chlorantraniliprole is a good candidate for replacing the hazardous methomyl in attracticide products. Chlorantraniliprole at $\mathrm{LC}_{20}$ or $\mathrm{LC}_{50}$ concentrations had sublethal effects, reducing egg-hatching and the longevity of female adults, and the $\mathrm{LC}_{50}$ concentration reduced fecundity. These negative effects may be related to the mechanism of action of chlorantraniliprole, which acts on the ryanodine receptors in insects and affects calcium homeostasis in the cell, leading to feeding cessation, lethargy, muscle paralysis, and ultimately, death of the insect [35].

The toxicity of chlorantraniliprole, flubendiamide, and emamectin benzoate was high against the moths, in accordance with their high toxicity against larvae [3,20]. However, the moths appeared to be less susceptible to chlorfenapyr compared with their larvae [36], indicating that the developmental stages have inherent differences in their susceptibility [37]. S. litura larvae having the ability to develop high resistance to chlorantraniliprole [38], further research is needed on whether moths can easily develop resistance to chlorantraniliprole. The rapid incapacitation and killing of moths is critical to an effective attractant to reduce adult opportunity to lay eggs before death. The $\mathrm{LT}_{50}$ of chlorantraniliprole against $S$. litura moths was found to be low; therefore, its high insecticidal toxicity and rapid efficiency against target pests make it a good candidate for controlling $S$. litura moths.

In the current study with $S$. litura, the $\mathrm{LC}_{50}$ of chlorantraniliprole significantly reduced

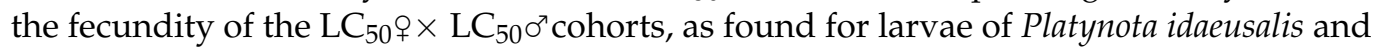
Helicoverpa zea that fed on a diet containing a sublethal concentration of tebufenozide $[39,40]$. Some insecticides can decrease egg-hatching [41,42]; however, our research showed that egg-hatching was also reduced when female and male moths that had been exposed to $\mathrm{LC}_{20}$ and $\mathrm{LC}_{50}$ concentration of chlorantraniliprole were paired with untreated male and female moths. Whether the reduction in hatching rate was caused by a decrease in mating rate or the lack of hatching of fertilized eggs needs further study. Our results indicate that 
future use of this compound in attract-and-kill schemes may not be limited by S. litura adult abundance or immigration rates, because egg-hatching will drop sharply even when untreated immigrants mate with the resident, pesticide-tainted individuals. Fieldwork, however, is essential to validate these hypotheses and fine-tune pesticide delivery methods.

The intrinsic rate of increase $\left(r_{\mathrm{m}}\right)$, a measure of the ability of a population to increase exponentially in an unlimited environment, provides an effective summary of an insect's life history traits [43], which, combined with a toxicity assessment, can provide a more accurate estimate of the population-level effect of a toxic compound [44-46]. In our study, $r_{\mathrm{m}}$ was lower for $\mathrm{LC}_{50}+\times \mathrm{LC}_{50} 0^{7}, \mathrm{LC}_{50} \uparrow \times \mathrm{CKo}^{\sigma^{\prime}}(0.14 \pm 0.02), \mathrm{CK}+\times \mathrm{LC}_{50} 0^{7}(0.14 \pm 0.01)$, $\mathrm{LC}_{20}+\times \mathrm{LC}_{20} \sigma^{\top}(0.15 \pm 0.01)$, and $\mathrm{CK}_{+} \times \mathrm{LC}_{20} 0^{7}$ cohorts after treatment with chlorantraniliprole compared with the controls, meaning a population increase would be delayed.

In conclusion, the novel insecticide chlorantraniliprole had the highest toxicity and fastest activity among the insecticides tested against $S$. litura moths. Thus, a low concentration will reduce $S$. litura fecundity and egg-hatching, and slow population growth. Hence, the inclusion of a low concentration of chlorantraniliprole in an attract-and-kill delivery scheme constitutes a highly desirable alternative to broad field-level applications or coating seeds with insecticide. Such an "attract-and-kill" measure will potentially enhance environmentally friendly pest management, and thus the IPM toolbox for controlling this global agricultural pest.

Author Contributions: Conceptualization, F.K., Y.S., and Y.L.; data curation: Q.Z., Z.W., and Y.L.; funding acquisition: Z.W., Y.L.; methodology, Q.Z.; project administration: F.K.; resources: F.K.; software, F.K., Y.S., and Y.L.; supervision: Y.L.; writing-original draft: F.K., and Y.L.; writingreview and editing: F.K., Y.S., and Y.L. All authors have read and agreed to the published version of the manuscript.

Funding: This study was supported by National Natural Science Funds of China (31701784), China Agriculture Research System (CARS-29) and National Key Research and Development Program of China (2018YFD0201300).

Institutional Review Board Statement: Not applicable.

Informed Consent Statement: Not applicable.

Data Availability Statement: The data presented in this study are available on request from the corresponding author. The data are not publicly available due to privacy.

Conflicts of Interest: The authors declare that they have no conflict of interest.

\section{References}

1. Ahmad, M.; Arif, M.I.; Ahmad, M. Occurrence of insecticide resistance in field populations of Spodoptera litura (Lepidoptera: Noctuidae) in Pakistan. Crop Prot. 2007, 26, 809-817. [CrossRef]

2. CABI. Invasive Species Compendium: Spodoptera litura (Taro Caterpillar). Available online: https://www.cabi.org/isc/ datasheet/44520 (accessed on 12 October 2019).

3. Su, J.Y.; Lai, T.C.; Li, J. Susceptibility of field populations of Spodoptera litura (Fabricius) (Lepidoptera: Noctuidae) in China to chlorantraniliprole and the activities of detoxification enzymes. Crop Prot. 2012, 42, 217-222. [CrossRef]

4. Huang, Q.; Wang, X.G.; Yao, X.G.; Gong, C.W.; Shen, L.T. Effects of bistrifluron resistance on the biological traits of Spodoptera litura (Fab.) (Noctuidae: Lepidoptera). Ecotoxicology 2019, 28, 323-332. [CrossRef]

5. $\mathrm{Wu}, \mathrm{R} . Z$. A survey on the peanut noctuids in Kwangtung province. Acta Entomol. Sin. 1977, 20, 445-450.

6. Yao, W.H. Biology characteristics of Prodenia litura. Entomol. J. East China 2005, 14, 122-127.

7. Qin, H.G.; Ye, Z.H. Occurrence and Management of the Common Cutworm, Spodoptera Litura in China; Agricultural Science and Technology Press: Beijing, China, 2007.

8. Armes, N.J.; Wightman, J.A.; Jadhav, D.R.; Rao, G.V.R. Status of insecticide resistance in Spodoptera litura in Andhra Pradesh, India. Pest Manag. Sci. 2015, 50, 240-248. [CrossRef]

9. Zhang, P.; Gao, M.; Mu, W.; Zhou, C.; Li, X.H. Resistant levels of Spodoptera exigua to eight various insecticides in Shandong, China. J. Pestic. Sci. 2014, 39, 7-13. [CrossRef]

10. Gregg, P.C.; Del Socorro, A.P.; Landolt, P.J. Advances in attract-and-kill for agricultural pests: Beyond pheromones. Annu. Rev. Entomol. 2018, 63, 453-470. [CrossRef]

11. Su, J.W.; Fan, W.M.; Wang, H.T.; Xuan, W.J; Sheng, C.F. Technology system for adult controlling of pest insect. Entoml. Knowl. 2001, 38, 405-409. 
12. Lu, Y.F.; Kan, H.L.; Li, L.L.; Zhuang, Q.Y.; Men, X.Y.; Guo, W.X.; Yu, Y. Preliminary evaluation of the monitoring and trapping efficacy of biological food attractant on Noctuidae adults in peanut fields in Junan county, Shandong province. Plant Prot. 2020, 46, 248-253.

13. Ma, X.F.; Yao, G.X.; Li, J.J. Control effect of tobacco-leaf moth attractant against Lepidopterous pests in tobacco field. J. Anhui Agri. Sci. 2013, 41, 6697-6698.

14. Wang, Y.H.; Liu, M.J.; Zhang, L.; Zhang, Z.R. New technology of monitoring and control of Lepidoptera pests in soybean fields. J. Anhui Agri. Sci. 2016, 44, 149-151.

15. Kong, D.S.; Sun, M.H.; Zhao, Y.L.; Xu, L.; Hui, X.H.; Qu, M.J.; Lu, X.T. Control effect and benefit analysis of sex attractant and biological food attractant on cotton bollworm in peanut field. Shandong Agric. Sci. 2016, 48, 102-105.

16. Gregg, P.C.; Del Socorro, A.P.; Henderson, G.S. Development of a synthetic plant volatile-based attracticide for female noctuid moth. II. Bioassays of synthetic plant volatiles as attractants for the adults of the cotton bollworm, Helicoverpa armigera (Hübner) (Lepidoptera: Noctuidae). Aust. J. Entomol. 2010, 49, 31-39. [CrossRef]

17. Farré, M.; Fernandez, J.; Paez, M.; Granada, L.; Barba, L.; Gutierrez, H.M.; Pulgarin, C.; Barceló, D. Analysis and toxicity of methomyl and ametryn after biodegradation. Anal. Bioanal. Chem. 2002, 373, 704-709. [CrossRef]

18. Liu, D.; Jia, Z.Q.; Peng, Y.C.; Sheng, C.W.; Tang, T.; Xu, L.; Han, Z.J.; Zhao, C.Q. Toxicity and sublethal effects of fluralaner of Spodoptera litura Fabricius (Lepidoptera: Noctuidae). Pestic. Biochem. Physiol. 2018, 152, 8-16. [CrossRef]

19. Maqsood, S.; Sabri, M.A.; Ali, A.; Abbas, M.; Aziz, A. Comparative toxicity of some insecticides against army worm, Spodoptera litura L. (Lepidoptera: Noctuidae) under laboratory conditions. J. Entomol. Zool. Stud. 2016, 5, 770-773.

20. Jameel, M.; Jamal, K. Efficacy of sub lethal concentration of flubendiamide against larvae of Spodoptera litura (Fab.) (Lepidoptera: Noctuidae). J. Entomol. Zool. Stud. 2017, 5, 670-674.

21. Lutz, A.L.; Bertolaccini, I.; Scotta, R.R.; Curis, M.C.; Favaro, M.A.; Fernandez, L.N.; Sánchez, D.E. Lethal and sublethal effects of chlorantraniliprole on Spodoptera cosmioides (Lepidoptera: Noctuidae). Pest Manag. Sci. 2018, 74, 2817-2821. [CrossRef]

22. Desneux, N.; Decourtye, A.; Delpuech, J.M. The sublethal effects of pesticides on beneficial arthropods. Annu. Rev. Entomol. 2007, 52, 81-106. [CrossRef]

23. Liang, G.M.; Wu, K.M.; Yu, H.K.; Li, K.K.; Feng, X.; Guo, Y.Y. Changes of inheritance mode and fitness in Helicoverpa armigera (Hübner) (Lepidoptera: Noctuidae) along with its resistance evolution to Cry1Ac toxin. J. Invertebr. Pathol. 2008, 97, 142-149. [CrossRef] [PubMed]

24. Gu, S.H.; Wu, K.M.; Guo, Y.Y.; Pickett, J.A.; Field, L.M.; Zhou, J.J.; Zhang, Y.J. Identification of genes expressed in the sex pheromone gland of the black cutworm Agrotis ipsilon with putative roles in sex pheromone biosynthesis and transport. BMC Genom. 2013, 14, 636. [CrossRef] [PubMed]

25. SPS Incorporation. SPSS 13.0 for the Windows; SPSS Inc.: Chicago, IL, USA, 2006.

26. Chi, H.; You, M.S.; Atlihan, R.; Smith, C.L.; Kavousi, A.; Özgökçe, M.S.; Liu, T.X. Age-stage, two-sex life table: An introduction to theory, data analysis, and application. Entomol. Gen. 2020, 40, 102-124. [CrossRef]

27. Huang, Y.B.; Chi, H. Life tables of Bactrocera cucurbitae (Diptera: Tephritidae): With an invalidation of the jackknife technique. J. Appl. Entomol. 2013, 137, 327-339. [CrossRef]

28. Swift, M.L. GraphPad prism, data analysis, and scientific graphing. J. Chem. Inf. Comp. Sci. 1997, 37, 411-412. [CrossRef]

29. Mensah, R.K.; Gregg, P.C.; Del Socorro, A.P.; Moore, C.J.; Hawes, A.J.; Watts, N. Integrated pest management in cotton: Exploiting behaviour-modifying (semiochemical) compounds for managing cotton pests. Crop Pasture Sci. 2013, 64, 763-773. [CrossRef]

30. Gregg, P.C.; Del Socorro, A.P.; Hawes, A.J.; Binns, M.R. Developing bisexual attract-and-kill for polyphagous insects: Ecological rationale versus pragmatics. J. Chem. Ecol. 2016, 42, 666-675. [CrossRef] [PubMed]

31. Saeed, Q.; Saleem, M.A.; Ahmad, M. Toxicity of Some Commonly Used Synthetic Insecticides against Spodoptera exigua (Fab) (Lepidoptera: Noctuidae). Pak. J. Zool. 2012, 44, 1197-1201.

32. Khan, R.A.; Rashid, M.; Wang, D.; Zhang, Y.L. Lethal and sublethal effects of cantharidin on the life history traits and population parameters of Helicoverpa armigera (Hübner) (Lepidoptera: Noctuidae). Pest Manag. Sci. 2014, 70, 39-45. [CrossRef]

33. Han, W.S.; Zhang, S.F.; Shen, F.Y.; Liu, M.; Ren, C.C.; Gao, X.W. Residual toxicity and sublethal effects of chlorantraniliprole on Plutella xylostella (Lepidoptera: Plutellidae). Pest Manag. Sci. 2012, 68, 1184-1190. [CrossRef]

34. Dong, J.; Wang, K.; Li, Y.; Wang, S.L. Lethal and sublethal effects of cyantraniliprole on Helicoverpa assulta (Lepidoptera: Noctuidae). Pestic. Biochem. Physiol. 2017, 136, 58-63. [CrossRef]

35. Lahm, G.P.; Selby, T.P.; Freudenberger, J.H.; Stevenson, T.M.; Myers, B.J.; Seburyamo, G.; Cordova, D. Insecticidal anthranilic diamides: A new class of potent ryanodine receptor activators. Bioorgan. Med. Chem. 2005, 15, 4898-4906. [CrossRef] [PubMed]

36. Xie, S.H.; Liang, Y.P.; Lin, Z.F.; Li, H.; Ji, X.C. The toxicity and control efficiency of 9 insecticides to Spodoptera litura. Plant Prot. 2010, 36, 175-177.

37. Leonova, I.N.; Slynko, N.M. Comparative study of insecticide susceptibility and activities of detoxifying enzymes in larvae and adults of cotton bollworm. Insect Biochem. Physiol. 1996, 32, 157-172. [CrossRef]

38. Muthusamy, R.; Vishnupriya, M.; Shivakumar, M.S. Biochemical mechanism of chlorantraniliprole resistance in Spodoptera litura (Fab) (Lepidoptera: Noctuidae). J. Asia-Pac. Entomol. 2014, 17, 865-869. [CrossRef]

39. Carpenter, J.E.; Chandler, L.D. Effects of Sublethal Doses of Two Insect Growth Regulators on Helicoverpa zea (Lepidoptera: Noctuidae) reproduction. J. Entomol. Sci. 1994, 29, 428-435. [CrossRef] 
40. Biddinger, D.; Hull, L.; Huang, H.; McPheron, B.; Loyer, M. Sublethal effects of chronic exposure to tebufenozide on the development, survival, and reproduction of the tufted apple bud moth (Lepidoptera: Tortricidae). J. Econ. Entomol. 2006, 99, 834-842. [CrossRef]

41. López, J.D., Jr.; Latheef, M.A.; Hoffmann, W.C. Mortality and reproductive effects of ingested spinosad on adult bollworms. Pest Manag. Sci. 2011, 67, 220-225. [CrossRef]

42. Quan, L.F.; Qiu, G.S.; Sun, L.N.; Li, Y.Y.; Yan, W.T.; Yue, Q.; Zhang, H.J. Sublethal effects of bate-cypermethrin on Carposina sasakii Walsingham (Lepidoptera: Carposinidae). Acta Entomol. Sin. 2017, 60, 799-808.

43. Dixon, A.F.G. Parthenogenetic reproduction and the rate of increase in aphids. In Aphids. Their Biology, Natural Enemies and Control; Minks, A.K., Harrewijn, P., Eds.; Elsevier: Amsterdam, The Netherlands, 1987; Volume A, pp. $269-287$.

44. Stark, J.D.; Tanigoshi, L.; Bounfour, M.; Antonelli, A. Reproductive potential, its influence on the susceptibility of the species to pesticides. Ecotoxicol. Environ. Saf. 1997, 37, 273-279. [CrossRef]

45. Walthall, W.K.; Stark, J.D. A comparison of acute mortality and population growth rate as endpoints of toxicological effect. Ecotoxicol. Environ. Saf. 1997, 37, 45-52. [CrossRef] [PubMed]

46. Forbes, V.E.; Calow, P. Is the per capita rate of increase a good measure of population-level effects in ecotoxicology? Environ. Toxicol. Chem. 1999, 18, 1544-1556. [CrossRef] 